\title{
U.S. Restitution of the Iraq Secret Police Files from Saddam Hussein's Regime Regarding the Kurds in Iraq
}

\author{
Ferdinand Hennerbichler ${ }^{1}$, Bruce P. Montgomery ${ }^{2}$ \\ ${ }^{1}$ The Presidency, Kurdology Center, University of Sulaimani, Kurdistan Region, Iraq \\ ${ }^{2}$ Director Archives \& Special Collections, University of Colorado Boulder, Colorado, USA \\ Email: ferdinand.hennerbichler@gmail.com, bruce.montgomery@colorado.edu
}

Received 15 January 2015; accepted 5 February 2015; published 10 February 2015

Copyright (C) 2015 by authors and Scientific Research Publishing Inc.

This work is licensed under the Creative Commons Attribution International License (CC BY). http://creativecommons.org/licenses/by/4.0/

c) (i) Open Access

\begin{abstract}
More than twenty years after Kurdish forces captured mass quantities of Iraqi secret police files chronicling the Anfal genocide and other events in their March 1991 uprising, a digital copy of these documents has been repatriated to Iraqi Kurdistan. Following the military transport of the documents to the U.S. and their scanning by the Defense Intelligence Agency, both a copy of these digital documents and the original files were acquired by the Archives at the University of Colorado-Boulder (CU-Boulder) in 1997. The files were thereafter made available to researchers and investigators from around the world searching for evidence to bring Saddam Hussein and his senior leadership to justice for grave violations of international humanitarian law. In 2012, Prof. Ferdinand Hennerbichler, an Austrian historian and former diplomat, and Prof. Bruce P Montgomery, director of the CU-Boulder Archives, commenced nearly two years of negotiations with the aim of restoring this archive of atrocity to the Iraqi Kurdish people. On September 30, 2014, in a formal high-level ceremony at CU-Boulder, a copy of the digital Iraqi secret police files was handed over to a visiting Kurdish delegation representing the Zheen Archive Center in Sulaimaniyah, which assumed custody of the files, and the regional government in Iraqi Kurdistan. The repatriated archive will be used to further reconciliation and democratization of the Kurdistan region and Iraq as a whole.
\end{abstract}

\section{Keywords}

Kurds, Iraq, Saddam-Hussein-Regime, Kurdish Genozide, Secret Police Files Former Torture Center Sulaimaniyah, U.S.-Digitalized Documents at UC-Boulder, Restitution to the Iraqi Kurds 


\section{Transfer Ceremony}

The repatriation ceremony was held on September 30, 2014, in the British Studies Room on the fifth floor of Norlin Library at the University of Colorado-Boulder (CU-Boulder) between 9:30 and 10:00 a.m. local time. It was attended by campus administrators, faculty, staff members, and guests of various disciplines and departments at UCB, among them Professor Bruce P. Montgomery, Director of Archives and Special Collections. The Dean of the Libraries James Williams II moderated the event. The campus Chancellor, Philip P. Distefano handed over an external hard drive containing the digital Iraqi Secret Police files to Ako M. Wahbi, the international representative of the Zheen Archive Center located in Sulaimaniyah, Iraqi Kurdistan. Dr. Barham A. Salih, former Vice Premier of Iraq and head of the government of the Kurdistan region, joined the ceremony live via Skype from Erbil, the capital of the Kurdistan region in Iraq. The incumbent Governor of Sulaimaniyah, Bahroz Muhammed Salih Faqe Rasheed, designated Woshiar Rasul Mohammed Amin, an adviser and former representative from a Kurdish Democratic Islamic Movement in the Sulaimaniyah Provincial Council, to attend the official repatriation event at CU-Boulder. The third member of the Iraqi Kurdish delegation included Prof. Ferdinand Hennerbichler who mediated the repatriation agreement between CU-Boulder and Iraqi Kurdish officials.

\section{University of Colorado at Boulder Program}

In addition to attending the repatriation ceremony, the three member delegation was invited to visit a number of class seminars on 29 and 30 September (Miller-Huey, 2014). In the seminars, the delegates explored topics such as revolution and political violence, the politics of ethnicity and nationalism, and state building in the $21^{\text {st }}$ century. One of the high points of their campus visit involved a public lecture by the delegates on the evening of 29 October 2014 in Butcher Auditorium, hosted by the university's Conference on World Affairs. The title of their talk, "The Future of the Kurds and Iraq: Confronting the Threat of ISIS," attracted a large audience and lively discussion with the delegates (Finley, 2014; Kuta, 2014; Lamp, 2014).

\section{Repatriation Ceremony}

The following morning at the repatriation ceremony James Williams II, Dean of the Libraries, in his introductory remarks, spoke of the first ever restitution of Iraqi secret police files to the people of Iraqi Kurdistan. The repatriation event in Boulder, he said, represented trust, promises kept, responsible leadership, legacy and friendship. Even before the handover of the files, he said, there had been a very public discussion on campus with the Iraqi Kurdish delegation about the future of the Kurds and of Iraq confronting the threat of ISIS.

\section{Repatriation}

Dean Williams then welcomed former premier Dr. Barham A. Salih who joined the repatriation ceremony live via Skype from the regional Kurdish capital Erbil. The Iraqi Secret Police Files of the Saddam Hussein era document more than 20 years of internal rebellion, insurrection, and war, explained Williams. These files also historically capture the genocide of the Kurdish people during the mid and late 1980s. Upon approval by the U.S. Senate Foreign Relations Committee, the Dean stated, these documents arrived in the safe custody of the Archives at the University of Colorado-Boulder. Archives Director Professor Bruce Montgomery, who negotiated the acquisition of these files, has attended to the documents with prudent and professional management. There had been an initial custody agreement with the Kurds and based on this understanding, CU-Boulder Chancellor Philip P. Distefano would now formally hand over a digital copy of the Iraqi Secret Police Files to the official delegation from Iraqi Kurdistan. As the designated representative, Ako M. Wahbi, received the digital Iraqi Secret Police files in his official capacity as the international board member of the Zheen Archive Center, which is where the repatriated records were to be housed in the Kurdistan region of Iraq.

\section{Official Repatriation of the Files}

"Mr. Wahbi, on behalf of the University of Colorado-Boulder, Norlin Library, the people of the State of Colorado, and the United States of America, I have the honor to present you with this official, digitized archive of the seized Iraqi intelligence documents." With these words, CU-Boulder Chancellor Distefano handed over an external hard drive with roughly 5.5 million pages of digitized records. 
Distefano also conveyed a greeting from Democratic Congressman Jared Polis, the U.S. representative of the Second District of Colorado. Due to scheduling difficulties, Representative Polis sent his state political chief of staff, Lisa Kaufmann, to the repatriation ceremony. Distefano described Jared Polis as a tireless advocate of the Kurdish people in the U.S. Congress, as co-founder of the Kurdish-American Congressional Committee in which he serves as vice president, and an advocate of a free and independent Kurdish Republic.

Chancellor Distefano also noted that UCB was a leading U.S. research university, having brought in more than $\$ 412$ million in research grants in the past year. Large research universities are "caretakers of the world's knowledge” with a global mission, he stressed.

\section{Comments}

"What a moment in history," said Dean Williams, continuing his remarks in hosting the repatriation ceremony. He then invited the three delegates representing Iraqi Kurdistan, Ako Wahbi, Woshiar Rasul, and Ferdinand Hennerbichler, to the podium. Responding to a question about what should happen to the repatriated files, Hennerbichler said: they should be used to aid the reconciliation between the peoples of the Kurdistan region and Iraq, who have been abused and torn apart by wars; to support them as they deal with their own tragic and bloody history of oppression, expulsion, and poison gas genocide under the now fallen Saddam Hussein regime; and to reinforce efforts for stabilization and democratization. Hennerbichler cited positive international examples in which such a process had succeeded, such as South Africa that overcame the former Apartheid system with a so-called Truth Commission and took the path to democracy. Or Germany, which continues to examine the Stassi archives of the former East German Staatssicherheit and has become a global model for democracy, as well as one of the most important geo-strategic partners of the United States. Hennerbichler also expressly thanked Archives Director Professor Bruce P. Montgomery, whom in the course of nearly two years of intensive cooperation, came to know and appreciate him not only as an outstanding personality and academic specialist, but also as a good friend. An intensification of contacts is planned.

\section{Coming to Terms with Kurdish History}

In other remarks, Ako Wahbi expressed deep gratitude to the University of Colorado-Boulder on behalf of the Zheen Archives Center and spoke of the documents' transfer as a historic moment. Wahbi praised in particular the years of intensive efforts by the University in preserving, safe guarding, and making available the Iraqi Secret Police Files. Now with their return to the Kurds in Iraq, these important original sources would be critically important in informing the Kurdish people of their history under the Saddam Hussein regime. The United States has repeatedly come to the aid of Iraqi Kurds at critical times. The U.S. not only rescued the Kurds in 2003 by overthrowing the former Saddam Hussein regime, but also is now assisting Kurdish peshmerga in their current battle against ISIS terror groups. Had American forces failed to carry out timely military airstrikes against ISIS onslaughts in northern Iraq, the Kurdish regional capital of Erbil would have been threatened by capture and catastrophe, Wahbi said. The United States has once again come to the decisive rescue of the Iraqi Kurds; for this, the Kurdish people are "very grateful."

Speaking in Kurdish, Woshiar Rasul, the delegate of the Sulaimaniyah Governorate, echoed Ako Wahbi's statement that the repatriation of the documents represented a historical moment. The United States had already liberated the Kurds from dictatorship and was now returning important historical documents to the Kurds. The restitution of these files would have positive consequences for the Kurds in illuminating the prior tragic events that befell the people of Iraqi Kurdistan. The Kurds have an exceedingly tragic history. The 1916 British-French Sykes-Picot Agreement divided the Kurds in four territorial regions in the Middle East, he explained. They were deprived of many fundamental rights, including the right to own a passport, study freely, or leave their cities. The former Iraqi regime even bombed and destroyed a Kurdish university established by freedom fighters in one of the liberated areas of Iraqi Kurdristan, Rasul continued. Finally, Saddam Hussein's forces used poison gas against the Iraqi Kurds in the "Anfal" campaign of the late 1980s. More than 180,000 Kurds were killed in this genocide. Ever since their liberation, the Iraqi Kurds feel that they are now regarded and accepted as real human beings with basic human rights. They have established their own regional government in Iraqi Kurdistan. Unfortunately, their regional capital of Erbil was on the brink of being captured by ISIS terrorists. But thankfully, the U.S. again intervened and came to the military aid of the Kurds. Rasul concluded his remarks by citing a surah 
from the Qur'an: those who grant someone a favor should follow it through. In other words, said Ako Wahbi who was translating Woshiar Rasul's talk for the repatriation event, the U.S. should now help the Iraqi Kurds achieve their long cherished historical dream of a free and independent Kurdish state.

\section{Barham Salih-Declaration by Skype}

At this moment in the repatriation ceremony, the internet Skype connection to the former Kurdish Premier Dr. Barham A. Salih once again broke down. The connection had already failed several times during the event. As a precaution, Ferdinand Hennerbichler video recorded the statement of Dr. Salih before the beginning of the ceremony and it was now shown in two parts on a screen behind the podium.

\section{Jalal Talabani-Barham Salih Initiative}

Barham Salih explained in detail how more than twenty years ago he acted on behalf of the future President of Iraq, Jalal Talabani, in securing the captured Iraqi Secret Police documents with the help of the United States. The repatriation of the files to the Iraqi Kurds is therefore personally for him an extraordinarily important event, which brings back significant memories, Salih declared. He returned "to his homeland" for the first time during the Gulf War in 1991 after ten years in exile. The leader of the Patriotic Union of Kurdistan (PUK) and the future head of the state of Iraq, Jalal Talabani, led him to an old house in Kurdistan and showed him "tons of documents" that were captured from Iraqi security agencies. He was "truly horrified when he saw details of the suppression campaigns by the Iraqi Bath Party regime against the Kurdish people," Salih said, and he was worried about the safety and safekeeping of these documents. Soon after, he returned to the U.S. and initiated intensive contacts to secure these documents with the support of the United States, including with the staff of the U.S. Senate Foreign Relations Committee on Capitol Hill and Andrew Whitely, former executive director of Middle East/Human Rights Watch. These officials showed immense interest in helping to secure these documents, Salih said. In the process, the idea arose of bringing the files to the U.S. To that effect, detailed negotiations ensued in the U.S., particularly with the Defense Department, and in Iraq, "with the Kurdish leadership." Many Kurds feared that the documents might be lost for good; both the Kurds and U.S. officials therefore urged that the files be transferred to the U.S. for safekeeping given their importance in chronicling the life of the Kurds and their suffering, said Salih.

At this critical moment, the U.S. once again proved to be "a friend of the Kurdish people" and took care of the documents, Salih continued. When the first files arrived at an airport in the U.S., that was "quite a moment, and the rest was also remarkable," recounted Salih. Andrew Whitely was present at the arrival of the first shipment of files to the U.S., as was Peter Galbraith, ${ }^{1}$ then a staffer with the U.S. Senate Foreign Relations Committee and later veteran U.S. diplomat, as well as Secretary of Defense Colin Powell.

An examination of the Iraqi Secret Police Files by independent experts, including analysts at MiddleEast/ Human Rights Watch and the Defense Department in Washington, unambiguously concluded that the events in Iraq and Kurdistan at that time constituted genocide against the Kurdish people, said Salih. The Kurds continue to be "truly grateful" for this assistance from the United States. They also are extraordinarily thankful to the University of Colorado-Boulder for keeping the documents safe and returning digital copies to the Iraqi Kurds. As a result, CU-Boulder has played a leading part "to write history, in order to ensure that such terrible events would not be repeated.” The former Kurdish Premier acclaimed again that through U.S. generosity, the Kurds would never again being threatened by genocide. This should not only be true for the Kurds but for all of humanity, above all, for those people who now confront the same terrible fate as the Kurds had in the past: Yezidis, Christians, Kurds again, Sunni, Shia, practically all people in Iraq and in the Middle East. Throughout history, the Kurds repeatedly said, "never again!” Unfortunately, the atrocities recurred and they are now being perpetuated by terror groups that threaten all segments of the population of Iraq. These escalating atrocities recall the "crimes of the Saddam Hussein regime against the Kurds" and show that this violence can flare up at any time, said Salih. He therefore stressed that it was "important and timely" to bring the digitized Iraqi Secret Police files back to Kurdistan and to make them accessible at the Zheen Archive Center in Sulaimaniyah. The world would thus be made aware of what hardship and suffering the Kurds and other peoples in Iraq have had to endure. He

${ }^{1}$ Peter Galbraith, at the time worked as a staffer on the U.S. Senate Foreign Relations Committee, who arranged the airlift of the documents out of Iraqi Kurdistan to the U.S. in 1992 and 1993. He and a group of colleagues had taken their first trip to northern Iraq in 1987. He now is a long serving U.S. diplomat. 
also emphasized the importance for the new, younger generation in Kurdistan to have access to these documents, as well as Kurdish researchers, to ensure that lessons are learned and that the future, in contrast to the past, can be completely shaped anew.

The former Kurdish Premier concluded his statements by thanking the University of Colorado-Boulder for all its efforts on behalf of the digitized files and invited CU-Boulder researchers to visit the Kurdistan region in Iraq and Sulaimaniyah to see for themselves how much the situation has dramatically improved and how grateful the Kurds are for U.S. assistance. He said academic cooperation already exists between the American University Sulaimaniyah Iraq (AUIS) and UCB in the training of engineers. Moreover, Kurds and Americans are connected by "something reaching across the Atlantic; a sense of humanity and the abhorrence of terrible atrocities against the Kurdish people." Salih expressed a two-fold gratitude: first, to U.S. forces for their decisive efforts to come to the rescue of the Kurds during the past two decades. And secondly, to U.S. researchers and academics for their remarkable work in securing the Iraqi Secret Police files, digitizing them, keeping them in safe custody, and finally repatriating them to the Iraqi Kurds. This now also enables Kurdish researchers to evaluate and assess the files. This terrible past should "never be repeated," Salih said. "Let us move on to a better future for all," he concluded.

\section{History of the Files}

The Iraqi secret police files were captured by the Iraqi Kurds in their March 1991 uprising against Saddam Hussein's regime immediately following the First Gulf War. In the popular revolt to gain autonomy over the Kurdish region in northern Iraq, the Kurds seized more than eighteen metric tons of documents from the three Kurdish governorates, primarily Sulaimaniyah but also from Dohuk and Erbil (Montgomery, 2001). Iraqi troops soon recaptured the Kurdish areas, however, sending hundreds of thousands of Kurds in desperate flight to the borders. In response, the United Nations Security Council set up a safe haven to protect the Kurdish population.

At the time, Peter Galbraith was a staff member of the U.S. Senate Foreign Relations Committee. In March and April of 1991, he travelled to Iraqi Kurdistan to study the Kurdish situation. While in northern Iraq, Galbraith was informed of the mass seizure of Iraqi secret police files-the largest captured collection of war crimes evidence since World War II (Montgomery, 2001, 2011, 2014). In a 1999 interview with Charles Stewart Kennedy, Galbraith explained the difficulties in securing and transporting the files to the U.S. as well as how the documents revealed the "cravenness of Saddam's regime."

In a March 1991 meeting in Iraqi Kurdistan with Jalal Talabani, founder of the Patriotic Union of Kurdistan (PUK) and later elected President of Iraq in 2005, Galbraith was told that the PUK seized vast quantities of Iraqi secret police documents. In the uprising in early March, the Kurds quickly captured the cities of Sulaimaniyah, Duhok, Zakho, Shaqlawah, and Kirkuk. In each of these cities, the headquarters of the secret police, intelligence agencies, and Baath Party were over run before the Iraqis could destroy or remove the files. The Kurds moved most of the files to the mountains before Iraqi forces could ruthlessly subdue the rebellion. When Galbraith returned to Iraqi Kurdistan in September 1991, the U.S. had intervened to protect the Kurds in northern Iraq after the First Gulf War. Given that the files documented grave violations of humanitarian law against the Kurdish people, Galbraith proposed to Talabani that the seized documents be transferred to the U.S. for safe keeping and where they could be exploited as evidence of war crimes. On behalf of the PUK, Talabani agreed to the proposal with the condition that the files remain the property of PUK. Similar arrangements were negotiated with the Kurdistan Democratic Party (KDP), which also seized a large number of Iraqi documents, and the Kurdish Socialist Party, which held a small quantity of materials.

The Pentagon subsequently airlifted the documents out of northern Iraq in 1992 and 1993 with support from the U.S. Senate Foreign Relations Committee, which exercised formal custody of the files. On their arrival in the U.S., the Defense Intelligence Agency (DIA) took possession and digitized the 5.5 million-pages of captured Iraqi secret police files for intelligence purposes. Following their scanning, the files were transferred to the temporary custody of the U.S. National Archive and Records Service in Washington (Montgomery, 2001; Gellman \& Randal, 1992; Kaslow, 1992). At the same time, an unusual collaboration ensued between the DIA and the New York-based human rights group, Human Rights Watch (HRW). Under this arrangement, HRW was granted exclusive access to analyze the files for a possible case of genocide against the Iraqi regime under the 1948 genocide convention.

In 1997, Professor Bruce P Montgomery of CU-Boulder, founder of a major human rights archive, negotiated 
the acquisition of the original files with the U.S. Senate Foreign Relations Committee; he also obtained a copy of the digital files from the DIA in Washington with the aim of exposing Saddam Hussein's crimes against the Kurdish people to the world community. The letter of transfer, signed by the Chairman of the U.S. Senate Foreign Relations Committee, Senator Jesse Helms of South Carolina, stated that a "request by the [Kurdish] parties for the return of their documents would be honored" and that this "commitment will bind any future custodian of these files.” (Montgomery, 2010; Human Rights Watch, 1993)

For nearly a decade, Prof. Montgomery managed these documents with considerable care, providing access to journalists, human rights groups, and the U.S. State Department' war crimes office looking for evidence to bring Saddam Hussein and his senior leadership to trial before an international tribunal under the 1948 Genocide Convention. These efforts failed to find sponsoring governments to bring formal charges under the Convention and it was not until after Saddam's overthrow in the 2003 U.S.-led invasion that charges were successfully brought against him in Iraq. In 2005, Prof. Montgomery agreed to turn over the original files to the U.S. Justice Department's Crimes Liaison Task Force, which was created to gather evidence for use in the Baghdad trials of Saddam and other regime officials for the crimes of the Anfal genocide. It is unclear whether these files were used in the trials and where they currently reside; their most probable location is at the Combined Media Processing Center at Camp As Sayliya, Qatar (CMPC-Q), which the U.S. built to handle the tens of millions of Iraqi regime documents seized in the 2003 invasion and subsequent occupation.

Prof. Montgomery advises that Kurdish Regional Government representatives (KRG) in Washington make inquiries as to the whereabouts of the original files with the aim of securing their return under the original agreement with the U.S. Senate Foreign Relations Committee. "If the Iraqi Kurds do not possess the original documents," Prof. Montgomery writes, "the KRG's Washington Office should make an inquiry about the status of the files in Washington; this inquiry should be addressed to the U.S. Senate Foreign Relations Committee which originally exercised formal custody of the files when they came to the U.S., designated the Kurds as the owners of the documents, and mandated that any request by the Kurds for the return of the files must be honored. Also, an inquiry should be made to the U.S. State Department and Justice Department should be made.”

\section{Return of the 5.5 Million-Page Digital Archive}

In September 2014, the repatriation of the 5.5 million-page digital archive was consummated at CU-Boulder with the formal hand over of a hard drive containing the scanned documents to international board member and representative of the Zheen Archive Center, Ako Wahbi. Almost a quarter of a century after the original documents were captured by Kurdish forces in the March 1991 uprising, the digital copy of the files now reside at the Zheen Archive Center in Sulaimaniyah in Iraqi Kurdistan. The return of the digital documents to the Iraqi Kurds stemmed from nearly two years of negotiations between Prof. Montgomery and Austrian historian and former diplomat Ferdinand Hennerbichler who mediated their restitution on behalf of the Zheen Archive Center and the regional government of Sulaimaniyah.

Hennerbichler assumed this role unexpectedly while conducting research for a monograph on "Austrian Middle-East-Peace Policy" under the late Chancellor Bruno Kreisky in the 1970s and 1980s. He also had been seeking accessible Iraqi intelligence documents in the U.S. regarding Austrian weapons shipments-specifically, sales of the Gun Howitzer Noricum GHN-45 long range artillery- to the former Saddam Hussein regime during the Iran-Iraq War in the 1980s. This search led him to the Iraqi Secret Police Files at CU-Boulder under the direction of Prof. Montgomery, one of the leading international experts in his discipline.

Although the prospect of ever returning these documents to the Kurdish people seemed impossibly remote when CU-Boulder first acquired them in the 1990s, given that Saddam Hussein remained firmly in power, Prof. Montgomery now saw the opportunity with Prof. Hennerbichler to restore a vitally important part of the Iraqi Kurds' historical patrimony. Following the 2003 American invasion and occupation of Iraq, Montgomery argued in an online essay that the documents belonged to the Iraqi Kurds, not to the new Iraqi central government in Baghdad as some were claiming. "As the victims of Saddam Hussein's outrages," he wrote, "they [Kurds] have the fundamental right to this recorded history—-their history—not the successor agencies to Hussein's secret police" which might well see to their destruction."”

\footnotetext{
${ }^{2}$ See "Iraqi Secret Police Files Seized by the Kurds During the First Gulf War,"

http://ucblibraries.colorado.edu/archives/collections/international.htm, 2008 (accessed 11 November 2014).
} 


\section{Position of the United States}

The University of Colorado-Boulder proceeded with repatriating the digitized files to the Iraqi Kurds after a careful review of its legalities under national and international law. In acquiring the files in 1997, Montgomery had already consulted with the relevant U.S. institutions, including the U.S. Senate Foreign Relations Committee, the Defense Intelligence Agency, and the National Archives and Records Service.

As already noted, the Senate Foreign Relations Committee stipulated in its letter of transfer with CU-Boulder that the Iraqi Kurds owned the secret police documents and that any request by them for their return must be honored. Despite initial concerns of returning secret police documents that could be put to misuse against individuals named in the documents, CU-Boulder was bound by this letter to honor these terms and move forward in good faith in returning these files to the Iraqi Kurds.

The restitution process advanced according the following negotiated principles:

1) The digitized files should be handed over to legitimate democratic representatives of the Kurdish people in Iraq, which would comport with the terms of the Senate Foreign Relations Committee. ${ }^{3}$

2) A copy of the digital files should be transferred to a professional archive in Iraqi Kurdistan where the documents could be made accessible for study and research; the Zheen Archive Center in the regional province of Sulaimaniyah was selected as the appropriate custodian of these files.

3) The Zheen Archive Center should send a representative to CU-Boulder to accept the formal transfer of the digital files on a hard drive and assume full responsibility for them.

4) The digital files of the secret police files at CU-Boulder's Archives would continue to remain globally available for research according to its specific access protocols.

The Kurdish delegation that visited CU-Boulder to receive a copy of the digital secret police files comprised several distinguished democratic representatives of Iraqi Kurdistan, including:

Dr. Barham Ahmed Salih, former Deputy Prime Minister of the Iraqi central government in Baghdad and Premiere of the federal, autonomous region of Iraqi Kurdistan based in Erbil;

Woshiar Rasul Mohammed Amin, advisor and delegate of the acting Governor of Sulaimaniyah, Bahroz Muhammad Salih Faqe Rasheed, as well as a former member of the Sulaimaniyah Provincial Council;

Ako M. Wahbi, board member and international representative of the Zheen Archive Center, and co-president of Plan Company, LTD, an energy and telecommunications firm;

Ferdinand Hennerbichler, an Austrian historian and faculty member of the Kurdology Center at the University of Sulaimaniyah, took part in the restitution process as a private, international coordinator and mediator who assisted in facilitating the repatriation of the secret police documents to the Iraqi Kurds.

\section{Preliminary Results}

An analysis of the secret police files has so far produced two results. First, the files have been recognized as evidence of "genocide” against the Kurds both by analysts in the U.S. and by courts in Iraq and Europe. Second, according to Prof. Montgomery, the documents reveal that as a rule, local and regional informants and collaborators of the former Saddam Hussein regime earned higher pay for their deeds than Iraq's security agents and officers.

As a final note, a comprehensive and conclusive processing of the files remains to done, making a full analysis of the materials impossible at this time. The evaluation of the documents poses a unique challenge, particularly for Kurdish researchers. Moreover, the CU-Boulder Archives and the Zheen Archive Center in Sulaimaniyah aim to establish an international collaboration to promote Kurdish culture and history. This relationship will expand CU-Boulder's academic cooperation with Kurdish research institutions and scholars; CU-Boulder, for example, already has established a cooperative arrangement with the American University Sulaimaniyah regarding the training of Kurdish engineers.

The CU-Boulder Archives has established access protocols governing research use of the Iraqi secret police files, given the sensitivity of the files in naming informants, collaborators, and others. The protocols are based on the Institutional Review Board process, mandated by the federal government to govern the ethical research

\footnotetext{
${ }^{3}$ In mid June 1992 the first Kurdish Regional Parliament, the Kurdistan National Assembly, and the first Kurdistan Regional Government (KRG) were formed and had convened. The highest democratically legitimized authority of Sulaimaniyah, where most of the "Iraqi Secret Police Files” where captured and secured in 1991, is the Sulaimaniyah Governorate, lead by a Provincial Council and Government, a Governor, and a Deputy. See e.o.: http://www.krg.org/p/page.aspx?l=12\&s=030000\&r=317\&p=229\&h=1\#elections_parliament.
} 
and confidentiality of human research subjects. This process has worked effectively in ensuring the legitimate use of the documents for academic research. ${ }^{4}$

\section{Documentation}

In addition to this written account, the author produced four video recordings of the repatriation ceremony on September 30, 2014 in the British Studies Room in Norlin Library at the University of Colorado-Boulder. ${ }^{5}$ The video recordings can be viewed and downloaded at these links:

- Former Torture Center of the Saddam Hussien Regime, Sulaimaniyah ${ }^{6}$

- Portrait, Dr. Barham Salih, Former Deputy Prime Minister Iraq, Kurdistan Regional Premier ${ }^{7}$

- Zheen Archive Center, Sulaimaniyah ${ }^{8}$

- Repatriation of the Iraqi Secret Police Files Seized by the Kurds During the 1991 Gulf War $^{9}$

\section{References}

Miller-Huey, M. (2014). UCB Press Release. http://www.colorado.edu/news/releases/2014/09/22/visiting-kurdish-delegation-receive-iraqi-secret-police-documents-cu

Finley, B. (2014). Iraq Kurds Collect History at CU, Want “new Israel” Kurdistan. The Denver Post, 1 October 2014. http://www.denverpost.com/environment/ci_26638715/iraq-kurds-collect-history-at-cu-want-new

Kuta, S. (2014). Iraqi Secret Police Files Returned to Kurdish Delegation at CU-Boulder. Documents Contain Parallels to Current Kurdish Fight against Islamic State. Daily Camera, 30 September 2014. http://www.dailycamera.com/cu-news/ci_26635126/iraqi-secret-police-files-returned-kurdish-delegation-at

Lamp, M. (2014). CU-Boulder to Give Kurdish Delegation Critical Historical Documents. Colorado Public Radio, 29 September 2014. http://www.cpr.org/news/story/cu-boulder-give-kurdish-delegation-critical-historical-documents

Montgomery, B. P. (2001). The Iraqi Secret Police Files: A Documentary Record of the Anfal Genocide. Archivaria, 52, 69-99. http://journals.sfu.ca/archivar/index.php/archivaria/article/viewFile/12815/14023

Montgomery, B. P. (2010). Counterpoint. Returning Evidence to the Scene of the Crime: Why the Anfal Files Should Be Repatriated to Iraqi Kurdistan. Archivaria, 69, 143-171.

Montgomery, B. P. (2011). Immortality in the Secret Police Files: The Iraq Memory Foundation and the Baath Party Archive. International Journal of Cultural Property, 18, 309-336. http://dx.doi.org/10.1017/S094073911100018X

Montgomery, B. P. (2014). US Seizure, Exploitation, and Restitution of Saddam Hussein's Archive of Atrocity. Journal of American Studies, 48, 559-593. http://dx.doi.org/10.1017/S0021875813002004

Gellman, B., \& Randal, J. C. (1992). U.S. to Airlift Archive of Atrocities Out of Iraq. The Washington Post, 19 May 1992 A12.

Human Rights Watch (1993). The Anfal Campaign against the Kurds. A Middle East Watch Report. Human Rights Watch. New York/Washington/Los Angeles/London, July 1993, Library of Congress Card Catalog Number: 93-79064. http://www.hrw.org/reports/1993/iraqanfal/

Kaslow, A. (1992). Documents Give Evidence of Atrocities against Iraqi Kurds. The Christian Science Monitor, 10 June 1992, $1,4$.

\footnotetext{
${ }^{4}$ More information on IRB's at the University of Colorado can found be found here: http://www.colorado.edu/vcr/irb/about-us.

${ }^{5}$ http://ucblibraries.colorado.edu/archives/KurdishDelegation.htm, retrieved 17 October 2014.

${ }^{6}$ http://ucblibraries.colorado.edu/archives/KurdishDelegationVideos.htm, retrieved 17 October 2014.

${ }^{7}$ L.C.

${ }^{8}$ L.C.

${ }^{9}$ L.c.
} 